\title{
Şiddeti Önlemede Pozitif Davranış Desteğinin Rolü*
}

\section{The Role of Positive Behavior Support in Preventing Violence}

\section{Özlem ÇEVíK ${ }^{[1]}$}

Başvuru Tarihi:16 Aralık 2020

Okulda var olan șiddet, eğitim öğretimi etkilemekle beraber bireylerin ve toplumun iyi olușunu ve güvenliliğini de tehdit etmektedir. Şiddeti önlemede çok çaba sarf edilmesine rağmen okullardaki şiddet ilkokul seviyesine kadar inmiştir. Şiddetle ilgili etkili bir tedbir alınmadığı takdirde şiddet artarak devam edecektir. Okuldaki şiddeti azaltmada etkili bir yol olabilecek Pozitif Davranış Desteğinin (PDD) sürekli kullanıldı̆̆ı okullarda alkol ve uyuşturucu kullanımı, okulu bırakma ve ayrılma gibi diğer davranış sorunları da başarılı bir şekilde azaltmıştır. Bu araştırmanın amacı PDD programının okuldaki şiddet davranışlarının düzeyi üzerinde etkili olup olmadığını incelemektir. Çalışma deneysel bir araştırma olup araştırmada öntest-sontest kontrol gruplu desen kullanılmıştır. Araştırmada yer alan denekler, Orhan Okay Mesleki ve Teknik Anadolu Lisesi'ne 2016-2017 eğitim-öğretim yılında devam eden 9. ve 10. sınıf öğrencileridir. Şiddet Eğilim Ölçeği, okula devam eden 221 öğrenciye uygulanmıştır. Ölçeğin sonucunda şiddet eğilimi yüksek 24 öğrenci belirlenmiştir. Bu öğrenciler seçkisiz olarak 12 kişi deney, 12 kişi kontrol gruplarına atanmıştır. Deney grubuna 8 hafta uygulanan PDD programı sonrasında çalışmanın bulgularına göre kontrol grubunun ön test ve son test puanı arasında anlamlı bir fark bulunmazken deney grubunun ilk test ve son test puanları arasında anlamlı bir fark bulunmuştur. Fakat her iki grubun son testi ve izleme testi arasında anlamlı bir fark bulunmamıştır. Çalışmanın sonucuna göre PDD şiddet eğilimini düşürmekte etkili olduğu söylenebilir.

Anahtar Kelimeler: pozitif davranış desteği, pozitif davranış, okullarda şiddet, şiddet davranışı, disiplin sorunları

Received Date:16 December 2020

Accepted Date:28 January 2021

The violence at school affects education but it threatens the well-being and safety of individuals and society. Although much effort has been made to prevent violence, the violence in schools has dropped to the level of primary school. Unless an effective measure of violence is taken, violence will continue to increase. Positive Behavior Support, which can be an effective way to reduce school violence, has also successfully reduced other behavioral problems such as alcohol and drug use, dropout and dropout in schools where it is continuously used. The aim of this study is to examine whether PBS program has an effect on the level of violent behavior at school. The study is an experimental research and the pretest-posttest control group design was used in the research. The participants in the research are 9th and 10th grade students attending Orhan Okay Vocational and Technical Anatolian High School in the 2016-2017 academic year. The Violence Tendency Scale was applied to 221 students attending school. As a result of the scale, 24 students with high violence tendency were determined. These students were assigned to 12 experimental groups and 12 control groups. According to the findings of the study, there was no significant difference between the pre-test and post-test scores of the control group, while a significant difference was found between the first and post-test scores of the experimental group. However, there was no significant difference between the posttest and follow-up test of both groups After the PDD program applied to the experimental group for 8 weeks, according to the findings of the study, there was no significant difference between the pre-test and post-test scores of the control group, while a significant difference was found between the experimental group's first test and posttest scores.

Keywords: positive behavior support, positive behavior, violence in schools, violence behavior, disciplinary issues

Çevik, Ö. (2021). Şiddeti önlemede pozitif davranış desteğinin rolü. Humanistic Perspective, 3 (1), 12-26. https://doi.org/10.47793/hp.842138

* Bu araștırma birinci yazarın doktora tezinden türetilmiștir. 


\section{GíRiş}

0 kul bireye ve topluma karşı pek çok görev ve sorumluluğa sahiptir. Okulların birey bazında akademik başarının yanı sıra sosyal ve duygusal başarının da sağlanmasında önemli bir görevi varken toplum bazında ise toplumun sahip olduğu değerleri koruyup yeni nesillere aktarma ve toplumun güvenli bir ortam olmasında önemli sorumlulukları vardır. Fakat okullar görev ve sorumluluklarını yerine getirirken bazı sorunlarla karşılaşmaktadırlar. Okullarda sık rastlanan sorunlardan biri olan şiddet davranışları ilkokul seviyesine kadar inmiştir (Hoşgörür ve Orhan, 2017). Okullarda var olan şiddet davranışları okul seviyesiyle birlikte farklılaşmasına rağmen öğrenci üzerinde bıraktığı olumsuz etki aynıdır. Şiddet davranışlarına yönelik etkili bir çözüm alınmadığı takdirde şiddet davranışları artarak ilerleyecektir (Gültekin, 2008; Sağkal, 2011; Uluçay, 2012; Hoşgörür ve Orhan, 2017). Okuldaki şiddet daha çok disiplin eksikliği olarak algılanmakta ve çözüm önerileri de genelde daha katı disiplin cezaları olabilmektedir. Fakat buna rağmen okulda şiddet varlığını sürdürmekte hatta şiddet şekli çeşitlenerek artmaktadır. Öğretmenler okuldaki disiplin sorunlarıyla uğraşmaktan çoğu zaman bitkin düşmektedir. Eğitim öğretim için ayrılması gereken zamanın çoğu disiplin sorunlarıyla başa çıkmada kullanılmaktadır. Bu durum eğitim durumlarını olumsuz etkilediği gibi öğretmenlerin de enerjisinin düşmesine, motivasyonlarını kaybetmelerine, tükenmişlik gibi sorunlar yaşamasına neden olmaktadır. Okullarda yaşanan şiddet olaylarından öğrencilerin de pek çok zarar gördüğü yapılan çalışmalarla ortaya konulmuştur. Yaşanan şiddet olaylarının, çocuk ve ergenlerin gelişimleri ve ruh sağlıkları üzerinde olumsuz etkileri olabilmektedir. Başta şiddet olmak üzere okulda yaşanan diğer disiplin sorunlarının azaltılmasında kullanılan pek çok yöntem işe yaramamaktadır. Okuldaki şiddet davranışlarını azaltmada etkili bir çözüm olan Pozitif Davranış Desteği etkili bir şekilde kullanıldığında akademik başarıyı ve sosyal becerileri de geliştirdiği pek çok çalışmayla kanıtlanmıştır. Pozitif Davranış Desteğinin etkin ve yaygın bir şekilde kullanıldığı okullarda, alkol ve uyuşturucu kullanımı, okulu bırakma ve ayrılma gibi diğer davranış sorunlarının da azaldığını görülmektedir (PBIS; Ruef, Higgins, Glaeser ve Patnode,1998; Wilson, Gottfredson ve Najaka, 2001; Anderson ve Kincaid, 2005; Horner, Sugai ve Anderson, 2010; Simonsen, JeffreyPearsall, Sugai ve McCurdy, 2011; Lacina ve Stetson, 2013; Bohanon ve Wu, 2014; Hoşgörür ve Orhan, 2017).

Pozitif Davranış Desteğine göre okullarda yaşanan şiddet gibi olumsuz davranışların en önemli nedeni öğrencilerin şiddet ve benzeri davranışları sergilerken çoğu zaman bu davranışların yanlış ve uygun olmadığını bilmemelerindendir. Pozitif Davranış Desteğine göre öğrencilere şiddet davranışın yanlış olduğu öğretildiğinde ve şiddet davranışının yerine bireyin işine yarayan etkili davranışlar kazandırıldığında istenmeyen davranışlar kendiliğinden ortadan kalkacaktır. Pozitif Davranış Desteğine göre şiddet gibi olumsuz davranışlar bulaşıcı bir hastalık gibi sağlıklı bireye de bulaşır (Ruef, Higgins, Glaeser ve Patnode,1998; Sugai ve Horner, 2006; Garcia, 2014;). Bu nedenle okulda şiddet davranışları sergileyen öğrencilere yönelik bir çalışma yapmak yetersiz ve etkisi az olacaktır. Okullarda şiddet davranışın azalarak ortadan kalkması için hem şiddet davranışı gösteren bireylere hem de şiddet davranışı göstermeyen bireylere eş zamanlı programlar uygulanmalıdır. Yoğun şekilde şiddet davranışı gösteren bireylere, bireysel pozitif davranış desteği programları; orta düzey ve az şiddet 
davranışı gösteren bireylere ise grupla pozitif davranış desteği programları; şiddet davranışı göstermeyen bireylere ise okul genelinde önleyici pozitif davranış desteği programları uygulanmalıdır (Johnston, Foxx, Jacobson, Green ve Mulick, 2006; Şahin ve Kesici, 2009; Pişkin, Öğülmüş ve Boysan, 2011; Garcia, 2014). Bu programlar uygulanırken şiddet davranışın ana kaynağı tespit edilmesi önemlidir. "Semptomları bırak hastalıkla ilgilen" mottosunu benimseyen Pozitif Davranış Desteğine göre şiddet davranışı gösteren bireylerin bu davranışı neden gösterdiği çok iyi bir şekilde analiz edildikten sonra şiddet davranışının nedeni bağlamında pozitif davranış desteği programları hazırlanmalı ve bu program bireye yeni pozitif davranışlar kazandırmalıdır. Bu programlar için şiddet davranışın yanlış olduğu uygun yöntemlerle bireye gösterilmelidir.

PDD okul genelinde uygulanan sürekli bir sistemdir ve verilere dayanır. PDD okuldaki tüm alanları (örneğin kantin, koridor, sınıf, okulun bahçesi) içine alan kapsamlı bir davranış destek sistemidir. PDD, öğrencilere okuldaki tüm alanlarda sergilenmesi gereken doğru davranışı öğretmeyi ve desteklemeyi hedefler. PDD’nin üç temel hedefi vardır; (a) problemli davranışın ortaya çıkmasını önlemek, (b) mevcut disiplin sorunlarını azaltmak ya da ortadan kaldırmak, (c) bütün öğrencilerin pozitif sosyal davranış sergilemesini artırmak (Turnbull ve ark., 2002; Safran ve Oswald, 2003; Anderson ve Kincaid, 2005; Pişkin, Öğülmüş ve Boysan, 2011). PDD, okulda şiddet davranışlarının engellenmesi ve olumlu güvenli bir okul iklimi için pozitif davranış desteğinin sürekli olarak verilmesini öngörür. Bu programlar en az 3 ya da 4 yıl boyunca uygulanmalıdır. PDD’nin uygulamasına göre sürekli olarak okuldaki durumla ilgi öğretmenlerden, öğrencilerden, velilerden veri toplanmalı böylelikle sorunun kaynağı tespit edilerek ihtiyaçlar doğrultusunda programlar geliştirilmelidir. PDD’ye göre her okulun ihtiyacı farklıdır ve her okulda yașanan şiddet olayları benzer olsa da farklıdır ve nedenleri de farklılık gösterecektir. Bu nedenle her okulun şiddet davranışlarını önlemede kendine özgü PDD programı olmalıdır (Sprague, Walker, Golly, White, Myers ve Shannon, 2001; Anderson ve Kincaid, 2005).

Okulun her yerinde sorunlu davranışları ortadan kaldırıp pozitif davranışları geliştirmeyi hedefleyen PDD, okulda sorunun en çok yaşandığı alanları tespit ederek ve orada yaşanan sorunun kaynağını bularak pozitif davranış geliştirmeye çalışır. Örneğin şiddet davranışlarının yaşandığı bir okulda, bu davranışların en çok nerede ve ne zaman hangi nedenlere ortaya çıktığını inceler. Bu şiddet davranışları en çok kantinde yaşanıyorsa oraya yönelik bir çalışma başlatır (Anderson ve Kincaid, 2005).

PDD’ye göre öğrenciler çoğu zaman doğru davranışın ne olduğunu bilmedikleri için sorunlu davranışlar sergilerler. Bu nedenle okulda öğrencilerden beklenen davranışların ve okul kurallarının açık ve net bir dille öğrenciye öğretilmesi gerekmektedir (Anderson ve Kincaid, 2005; Garcia, 2014). Örneğin “öğretmenlerine saygılı olmak" bu ifade öğrenci için belirsizdir. Bu nedenle hangi davranışların saygllı bir davranış olarak nitelendirildiğini öğrenciye öğretmek gerekmektedir. Her yaş grubunun ve her okulun özelliği farklı olduğu için öncelikli olarak okulun ve öğrencilerin özellikleri ve ihtiyaçları belirlenmeli ve bu doğrultuda programlar uygulanmalıdır. Benzer şekilde her yaşta ve her okulda görülen şiddet çeşidi ve nedeni farklıdır. PDD’ye göre okulun öğrenci profiline ve şiddetin türüne göre programlar geliştirilmelidir. Lise seviyesinde uygulanan PDD, 
öğrencilerin sosyal gelişimlerini ilkokul ve orta okuldaki öğrencilerinkinden daha fazla önemser. Fakat her okul seviyesinde PDD, şiddettin olmadığı ya da şiddet davranışlarının giderek azaldığı sınıf ve okul ortamları oluşturmayı amaçlar. PDD’ye programları ve PDD sistemiyle okullarda disipline gönderme durumunda ciddi bir düşüş görülür (Safran ve Oswald, 2003; Carney, 2005).

Okullarda yaşanan şiddet davranışları genellikle arkadaşına fiziksel şiddet uygulama, okul eşyalarına zarar verme, küfürleşme, ötekileştirme, arkadaşının malına kasıtlı olarak zarar verme, güçsüzleri kenara itme ve gruba dahil etmeme, kontrolsüz öfke, devrecilik davranışları, çeteleşme, laf atma, alkol kullanımı, itmekakma, kavga, arkadaşını aşağılama, çeteleşme, zorla bir şey kabul ettirmeye çalışma gibi davranışlar olarak görülse de bu davranışların kendisi ve bu davranışların ortaya çıkış nedeni her okulda farklılık gösterebilmektedir (Hoşgörür ve Orhan, 2017). Okullardaki şiddet davranışları, okul dışındaki aile, akran grubu, sosyal medya gibi diğer alanlardan bağımsız değildir. Öğrencinin dünyasındaki ve içinde bulunduğu toplumdaki şiddettin bir uzantısı veya yansımasıdır. Okullarda yaşanan şiddetin nedeni çoğu zaman ailenin çocuğu yetiştirme tarzından, aile içi şiddetten, öğrencinin içinde bulunduğu çevreden, görsel medyadaki şiddet içeren yapımlardan, öğrencinin akademik başarısızlık olabilmektedir. Bunun yanı sıra insanı şiddete yönelten pek çok unsurun varlığından da söz etmek mümkündür. Bunlar; Beyin kimyası, yetiştirilme tarzı, çevre, kültür ve kişinin çevresinde bulunan şartlar (Trend, 2008). Ayrıca, şiddet davranışın ortaya çıkmasında çok sayıda etkenin etkileşim sürecinden söz etmek mümkündür. Bu nedenle şiddet davranışı gösteren bireyler içinde bulundukları çevre, sosyalleştikleri kurumlar ve sosyo-kültürel ve ekonomik durumları içerisinde incelenmelidir (Koç, 2011). Şiddet, çoğu zaman olumsuz sosyo-kültürel ve ekonomik şartlar içerisinde öğrenilen bir olgudur ve şiddet öğrenilen bir olgu olduğuna göre eğitimle önlenmesi de mümkündür (Yayla, 2013; Hoşgörür ve Orhan, 2017). Ayrıca okullarda bireye pozitif davranış kazandırmak farklı bir ortamda pozitif davranış kazandırmaktan daha kolaydır. Okulda oluşturulacak PDD sistemiyle okul çalışanlarına ve öğrenciye pozitif davranış kazandırılabilir (Bohanon ve Wu, 2014).

Son yıllarda ülkemizdeki okullarda şiddettin arttığına dair söylemler vardır (Kızmaz, 2006) ve çoğu zaman şiddet bir sorun çözme yolu olarak öğrenciler tarafından seçilmektedir (Gürsoy, 2009). Bu da güvenli okul kavramını daha fazla gündeme taşımaktadır; çünkü güvenli bir okul ortamı öğrencilerin duygusal ve davranışsal sorunlar yaşama olasılığını düşürür ve öğrencilerin psikolojik ihtiyaçlarını karşılar (Knoff, 2000; Çalık, Kurt ve Çalık, 2011). Ayrıca okulların akademik bilgi kazandırmanın yanı sıra öğrenciye toplumsallaşmada destek sağlayacak pozitif davranışları da kazandırması önemlidir. Bunun için de okulların şiddetten arındırılmış güvenli okullar olması önemlidir. Bu yüzden güvenli bir ortamı için yapılan araştırmalar ve atılacak adımlar ve bu yöndeki araştırma ve çalışmalardan elde dilen bulguların eğitim paydaşlarıyla paylaşılması hem şiddetin önlenmesinde hem de şiddetten arınmış güvenli okul ortamlarının oluşturulmasında önemlidir (Knoff, 2000; Koç, 2011).

\section{Problem.}

Araştırmanın problemi kısaca şöyledir: 
1. Okullardaki şiddet davranışı ilkokul kademesine kadar inmiştir.

2. Okullarda uygulanan disiplin cezaları şiddet problemini çözmede yetersiz kalmaktadır.

3. Okullardaki şiddet davranışları öğrencilerin eğitim durumları ile akademik ve sosyal becerilerini olumsuz yönde etkilemektedir.

\section{Amaç.}

Bu araștırmanın amacı PDD programının lise öğrencileri arasındaki şiddet davranışları düzeyi üzerinde etkili olup olmadığını incelemektir.

\section{YÖNTEM}

\section{Araștırmanın Modeli}

Deneysel bir araştırma olan çalışmada öntest-sontest kontrol gruplu desen kullanılmıştır. Araştırmanın deseni Tablo 1'de gösterilmiştir Çalışmada kullanılan 2x3'lük split-plot (karışık) desenden birinci faktör işlem gruplarını (bir deney, bir kontrol); ikinci faktör bağımlı değişkene ilişkin ölçümleri (öntest, sontest ve izleme) göstermektedir.

\section{Tablo 1}

Araştırma deseni

\begin{tabular}{lcccc}
\hline Grup & Ön test & İșlem & Son test & İzleme \\
\hline Deney & Ö1 & PDDP & Ö2 & Ö3 \\
Kontrol & Ö1 & SP & Ö2 & Ö3 \\
\hline
\end{tabular}

Tablo 1'de gösterilen PDDP, Pozitif Davranış Desteği Programı'nı, Serbest Etkinlik Programı kontrol grubuna uygulanan işlemi göstermektedir. Ö1, Ö2 ve Ö3 sırasıyla öntest, sontest ve izleme ölçümlerini göstermektedir. Modelde bir bağımsız ve iki bağımlı değişken bulunmaktadır.

Çalışmanın bağımsız değişkeni Pozitif Davranış Desteği Programı; bağımlı değişkenleri ise öğrencilerin şiddete eğilim düzeyleri ve zaman faktörüdür. Deney grubuna 8 haftalık PDD uygulanmıştır. Kontrol grubuna ise Serbest Etkinlik Programı uygulanmıştır.

\section{Deneysel Çalışmada Gruplara Atama}

$\mathrm{Bu}$ araştırma deneysel bir çalışma olduğu için bir evren ve örnekleme çalışması yapılmamıştır. Çalışmada, "araştırma grubu" kullanılmıştır. Araştırma grubu, Van/Edremit Orhan Okay Mesleki ve Teknik Anadolu Lisesi'nden seçilmiştir. Bu öğrenciler 2016-2017 eğitim öğretim yılında 9. ve 10. sınıfa devam eden öğrencilerdir. 221 öğrenciye kişisel bilgi formu, Şiddet Eğilim Ölçeği uygulanmıştır. Ölçekten alınan puanlar 20 ila 60 arasında hesaplanmaktadır. Ölçekten alınan puan yükseldikçe bireyin şiddet eğiliminin yüksek olduğunu göstermektedir. Bu araştırmadaki 221 öğrencinin şiddet eğilim puanın SPSS aracılı̆̆ıyla hesaplandı. Şiddet Eğilim Ölçeğinden 40 ila 50 puan arasında puan alan 24 öğrenci araştırmaya dahil edildi. Formlar katılımcılara dağıtılırken her katılımcıdan birer rumuz yazmaları istemiş ve veriler toplandıktan sonra en yüksek puanı alan 24 
katılımcıya rumuzları doğrultusunda ulaşılmıştır. Daha sonra araştırmaya gönüllü olarak katılacaklarını belirtmeleri üzerine araştırmanın deney ve kontrol gruplarına dahil edilmişlerdir.

Deney grubuna öğrenciler seçkisiz olarak atanmıştır. Deney ve kontrol grubundaki öğrencilerin cinsiyet ve sınıfa göre dağılımları Tablo 2'de gösterilmiştir.

\section{Tablo 2}

Deney ve kontrol grubunu oluşturan öğrencilerin cinsiyetlere ve sınıflara göre sayısal dağılımları

\begin{tabular}{lcccc}
\hline & Deney Grubu & & \multicolumn{2}{c}{ Kontrol Grubu } \\
\hline Sinıf & Kiz & Erkek & Kiz & Erkek \\
\hline 9. Sinıf & & 4 & 1 & 3 \\
10. sinıf & 1 & 7 & & 8 \\
Toplam & 1 & 11 & 1 & 11 \\
\hline
\end{tabular}

Tablo 2'de görüldüğü üzere, deney ve kontrol gruplarında yer alan öğrencilerin toplam sayısı 24'tür. Her iki grupta da 9. sınıftan 4; 10. sinıftan 8 öğrenci vardır. Ayrıca her iki grupta da 1 kız, 11 erkek mevcuttur. Fakat deney grubunda yer alan kız öğrenci 10. Sınıf öğrencisi iken kontrol grubunda yer alan kız öğrenci 9. Sınıf öğrencisidir.

Çalışmada yer alan 24 öğrencinin Şiddet Eğilimi Ölçeği'ne göre öntestte aldıkları şiddet eğilim puanları ve sınıflara göre dağılımı Tablo 3'te gösterilmiștir.

\section{Tablo 3}

Araştırmada yer alan öğrencilerin ön test șiddet eğilim puanlarının sınıflara göre dağılımı

\begin{tabular}{cccccccccc}
\hline & \multicolumn{10}{c}{ Şiddet Ölçeği Ön Test Sonuçları } \\
\hline & $\mathbf{4 0}$ & $\mathbf{4 1}$ & $\mathbf{4 2}$ & $\mathbf{4 4}$ & $\mathbf{4 5}$ & $\mathbf{4 7}$ & $\mathbf{4 8}$ & $\mathbf{5 0}$ & Toplam \\
\hline 9. Sınıf & 4 & 1 & 2 & 0 & 0 & 1 & 0 & 0 & $\mathbf{8}$ \\
10. Sınıf & 4 & 3 & 4 & 2 & 1 & 0 & 1 & 1 & $\mathbf{1 6}$ \\
Toplam & 8 & 4 & 6 & 2 & 1 & 1 & 1 & 1 & $\mathbf{2 4}$ \\
\hline
\end{tabular}

Tablo 3'te görüldüğü gibi Şiddet Eğilim Ölçeği'nden en yüksek puanı alan 24 öğrenciden 16'sı 10. sınıf, 8'i ise 9. Sınıf öğrencisidir. Şiddet Eğilim Ölçeği'nden 40 puan alan 8 öğrenciden 4'ü 9. sınıf, 4'ü 10. Sınıf öğrencisidir; 41 puan alan 4 öğrenciden 1'i 9. sınıf, 3'ü 10. sınıftır; 42 puan alan 6 öğrenciden 2'si 9. sınıf, 4'ü 10. sınıftır; 44 puan alan 2 öğrenci 10. Sınıf öğrencisidir; 45 puan alan 1 öğrenci 10. Sınıf öğrencisidir; 47 puan alan 1 öğrenci 10. Sınıf öğrencisidir; 48 puan alan 1 öğrenci 10. Sınıf öğrencisidir; 50 puan alan 1 öğrenci 10. Sinıf öğrencisidir.

\section{Verilerin Toplanması}

Araştırmada veri toplama aracı olarak Şiddet Eğilim Ölçeği ve Kişisel Bilgi Formu kullanılmıştır. Ölçek, deneysel işlemden bir ay önce, işlem bitiminde iki ay sonra uygulanmıştır. Öğrencilerin ölçeğin isminden etkilenerek yanlı cevap vermemeleri için ölçeğin ismi ölçeğin üzerine yazılmadan veriler toplanmıştır. 
Şiddet Eğilim Ölçeği. Haskan ve Yıldırım (2012) tarafından geliştirilen ölçek, 3'lü likert tipi olup 20 madden oluşmaktadır. Ölçekten alınan en düşük puan 20 en yüksek puan ise 60'tır. Ölçekten alınan puan arttıkça şiddet eğilimleri de artmaktadır. Cronbacha alfa katsayısı .87; test tekrar test güvenirliği ise .83'tür. Ölçekle ilgili yapılan geçerlik ve güvenirlik çalışmaları ölçeğin şiddet eğilimi ölçmek için kullanılabileceğini göstermiştir. Ölçeğin güvenirlik analizinde Cronbacha alfa katsayısı .87; test tekrar test güvenirliği ise .83 olarak belirlenmiştir. Ölçeğin geçerlilik ve güvenirlik ile ilgili yapılan çalışmalar, ölçeğin lise öğrencilerinin şiddet eğilimini ölçmek için kullanılabileceğini göstermiştir.

Kişisel Bilgi Formu. Araştırmacı tarafında geliştirilen kişisel bilgi formunda öğrencilerin sınıfı ve cinsiyeti ile ilgili bilgiler yer almıştır.

\section{Verilerin Analizi}

Şiddet Eğilim Ölçeği'yle toplanan veriler SPSS paket programıyla analiz edilmiştir. Öntest ve sontest puanları arasında fark olup olmadığı iki faktörlü varyans analizi (ANOVA) ile test edilmiștir. Deney ve kontrol gruplarının şiddet eğilimi öntest, sontest ve izleme puanlarının ortalamalarının karşılaştırılmasında ise Posthoc testlerinden "Bonferonni" testi ile yapılmıştır. İstatistiksel işlemler için hata payı .05 kabul edilmiştir.

\section{BULGULAR VE YORUM}

Seçkisiz olarak belirlenen gruplar arasında bir fark olup olmadığını test etmek için t testi uygulanmıştır. t testi sonuçları Tablo 4'te gösterilmiştir.

\section{Tablo 4}

Deney ve kontrol gruplarının deneysel işlem öncesi Şiddet Eğilimi Ölçeğinden aldıkları puanların ortalamalarının karşılaştırılması için t-testi tablosu

\begin{tabular}{lcccccc}
\hline Grup & N & Ortalama & Standart Sapma & t & sd & p \\
\hline Kontrol & 12 & 41.91 & 2.74 & .581 & 21.954 & .567 \\
\hline Deney & 12 & 42.58 & 2.87 & & & \\
\hline
\end{tabular}

Tablo 4'te göre t- testi sonucu; Deney grubunun işlem öncesi şiddet eğilim puanlarının ortalaması $(x=42,5833)$ ile kontrol grubunun işlem öncesi şiddet eğilim puanları ortalaması $(x=41,9167)$ arasında istatistiksel olarak anlamlı bir fark yoktur $(\mathrm{t}(21,954)=.581 ; \mathrm{p}>.05)$.

Deney ve kontrol gruplarının öntest ve sontest ve izleme puanlarının ortalamaları, standart sapma değerleri ve denek sayıları Tablo 5’te gösterilmiştir.

\section{Tablo 5}

Deney ve Kontrol Gruplarının Şiddet Eğilim Ölçeği Öntest, Sontest ve İzleme Puanlarının Aritmetik Ortalama ve Standart Sapma Değerleri 


\begin{tabular}{lccccccccc}
\hline Ölçüm & \multicolumn{3}{c}{ Ön Test Puanları } & \multicolumn{3}{c}{ Son Test Puanları } & \multicolumn{3}{c}{ İleme Test Puanları } \\
\hline Grup & $\mathbf{N}$ & $\overline{\mathbf{x}}$ & $\mathbf{S}$ & $\mathbf{N}$ & $\overline{\mathbf{x}}$ & $\mathbf{S}$ & $\mathbf{N}$ & $\overline{\mathbf{x}}$ & S \\
\hline Kontrol & 12 & 41.91 & 2.87 & 12 & 38.25 & 5.154 & 12 & 38.08 & 8.18 \\
Deney & 12 & 42.58 & 2.74 & 12 & 33.58 & 4.62 & 12 & 38.83 & 5.21 \\
Toplam & 24 & 42.25 & 2.77 & 24 & 35.91 & 5.34 & 24 & 38.45 & 6.72 \\
\hline
\end{tabular}

Tablo 5’e göre ortalama puanlara bakıldığında kontrol grubuna göre "Pozitif Davranış Desteği Programı” alan deneklerin şiddet eğilimi düzeylerinde bir değişim olmuştur.

İki ayrı deneysel işlem alan deney ve kontrol grubunun deneklerinin şiddet eğilimi düzeylerinde, “Pozitif Davranış Desteği Programı”nın öncesine göre program sonrasındaki değişimlerin anlamlı bir fark gösterip göstermediğiyle ilgili Split-plot ANOVA sonuçları Tablo 6’da gösterilmiştir.

\section{Tablo 6}

Deney ve Kontrol Gruplarının Şiddet Eğilimi Öntest-Sontest ve İzleme Testi Puanlarına İlişskin ANOVA Sonuçları

\begin{tabular}{lccccc}
\hline Varyansın Kaynağı & KT & Sd & KO & F & P \\
\hline Denekler arası & 1047.87 & 23 & & & \\
Grup (Deney/Kontrol) & 21.12 & 1 & 21.12 & .453 & .508 \\
Hata & 1026.75 & 22 & 46.67 & & \\
Denekler içi & 1313.99 & 48 & & & \\
Ölçüm (Öntest/ & 487.58 & 2 & 243.79 & 15.09 & .000 \\
Sontest/İzleme) & & & & & \\
Grup*Ölçüm & $\mathbf{1 1 5 . 5 8}$ & $\mathbf{2}$ & $\mathbf{5 7 . 7 9}$ & $\mathbf{3 . 5 7}$ & $\mathbf{0 . 3 6}$ \\
Hata & 710.83 & 44 & 16,15 & & \\
Toplam & 2361.87 & 71 & & & \\
\hline
\end{tabular}

Grup ve ölçüm temel etki testlerinin sonuçlarına bakıldığında, "Pozitif Davranış Desteği Programı"na katılan deneklerin şiddet eğilimi puan düzeylerinin deney öncesinden sonrasına anlamlı bir farklılık göstermiştir $[\mathrm{F}(2,44)=3,577, \mathrm{p}<.05]$. Grupların ortalamalarındaki değişime bakıldığında deney grubundaki değişim kontrol grubundaki değişimden daha fazladır. Bu değişimler arasında anlamlı farklılık olup olmadı̆̆ Bonferonni testiyle incelenmiştir.

\section{Tablo 7}

Deney ve Kontrol Gruplarının Öntest-Sontest ve İzleme Testlerine Göre Şiddet Eğilim Ölçeğinden Aldıkları Puanların Ortalamalarına İlişkin post-hoc tablosu

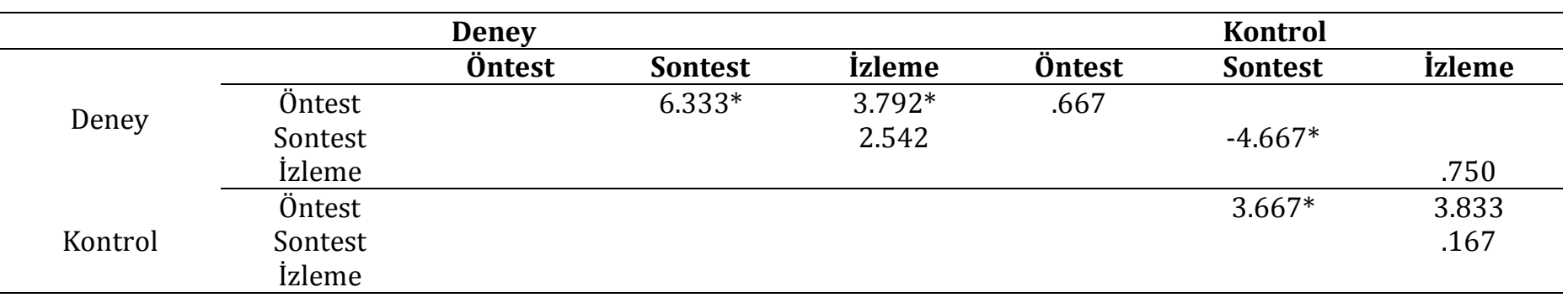

${ }^{*} \mathrm{p}<.05$ 
Pozitif Davranış Desteği Programı́nın şiddet eğilimi puanlarının deney grubunun ön test ve son test puanları arasında anlamlı bir fark bulunurken son test ile izleme testi arasında anlamlı bir fark bulunamamıștır.

\section{SONUÇ, TARTIŞMA VE ÖNERÍLER}

Okuldaki şiddet başta olmak üzere, eğitim ortamlarında yaşanan disiplin sorunları, eğitim ve öğretim çalışmalarını sekteye uğratmaktadır ve alanda çalışanların motivasyonunu düşürmektedir. Okullar çoğu zaman şiddet başta olmak üzere yaşanan disiplin sorunlarını ceza yöntemleriyle çözmeye çalışmaktadır. Bazen de okuldaki şiddet davranışlarını önlemek için öğretmenleri bilgilendirme, öğrencilerle birlikte kurallar belirleme, riskli alanları denetim altında tutma, okul kurallarını taviz vermeden uygulama, okulda konferanslar düzenleme, okul dışından destek sağlama, öğrencilerle iletişim kurma, sosyal etkinlikler düzenleme, okulda pano oluşturma, öğrencileri bilgilendirme, polisiye tedbirler alma, velilerle işbirliği yapma ve öğrenci velileri ile iletişim kurma şeklinde çözüm yolları olabilmektedir (Hoşgörür ve Orhan, 2017). Fakat kullanılan pek çok yönteme rağmen okullardaki şiddet sorunları devam etmektedir. Avrupa ve Amerika'da şiddet ve okullarda yaşanan disiplin sorunları için Pozitif Davranış Desteği yaygın bir şekilde kullanılmaktadır. PDD’nin etkili ve sürekli kullanıldığı okullarda şiddet ve benzeri sorunlar azalmaktadır.

PDD programının şiddet eğilimine etkisini inceleyen bu araştırma deneysel bir çalışmadır. Pozitif Davranış Desteği Programının şiddet eğilimi davranışına etkisi incelendiğinde deney grubunun ön test ve son testi arasında anlamlı bir fark bulunmuştur. Bu bulgu önceki çalışmalarla benzerlik göstermektedir. Simonsen, Sugai ve Negron'nun (2008) yaptıkları çalışmalarında okullarda yaşanan disiplin sorunları ve öğrenciler arasında görülen saldırganca davranışların PDD sistemi içerisinde çözüme ulaştığını belirtmektedirler. Benzer şekilde, Wilson, Gottfredson ve Najaka (2001), PDD ile ilgili yapılmış çalışmaları meta analizle incelemişlerdir. Çalışmalarında 165 okulun PDD programı incelenmiştir ve yaptıkları çalışmanın sonucuna göre PDD okullardaki problemli davranışları azaltmada etkili olmuştur.

$\mathrm{Bu}$ araştırmada ön test ve son test arasında anlamlı fark bulunmasına rağmen son test ve izleme testi arasında anlamlı bir fark bulunmamıştır. PDD programı şiddet eğilimini düşürmede başarılı olmasına rağmen bu iyi halin devamı gözlenmemiştir. Bu bulgu PDD kuramıyla uyumluluk göstermiştir. PDD’ye göre okuldaki sorunlu davranışların azalması ve iyi halin devam edebilmesi için PDD’nin sürekli olması gerekmektedir (Knoff, 2000). Diğer bir deyişle okulun iklimin de sürekli olarak iyi olması gerekmektedir; çünkü okul iklimi öğrencileri şiddete yönelten etmenler arasında yer almaktadır (Gürsoy, 2008). PDD’nin başarılı bir şekilde yürütüldüğü okullarda PDD, tüm öğrencilere yönelik uygulanmakta ve sürekli olarak yapılmaktadır. Gottfredson, Gottfredson ve Hybl (1993), başarılı bir şekilde yürüttükleri PDD sekiz ortaokulda 3 yıl boyunca uygulanmıştır. Benzer şekilde Nelson (1996), 2 ilkokulda sorunlu ve aşırı davranışlar sergileyen öğrencilere göre hazırlanmış okul genelinde PDD programını değerlendirmek için 2 yıldan fazla süreyle incelemeler yapmıştır. 


\section{Öneriler}

Şiddeti önleme bir program dahilinde yürütüldüğünde başarıya ulaşmaktadır. PDD programları şiddet türü davranışları engellemekte başarılı olmuştur. Bu nedenle okullarda şiddet davranışlarını engellemek için PDD programları geliştirilebilir.

Okuldaki şiddet davranışlarını engellemede kalıcı bir başarı kazanmak için verilen hizmetlerin sürekli olması ve programların yenilenerek uygulanması fayda sağlayabilir. Bu nedenle şiddeti önlemeye yönelik geliştirilen PDD programlarının sürekli olması şiddet davranışlarının önlemede istenen faydayı sağlayacağı düşünülmektedir.

Okullarda şiddeti önlemek için sadece şiddet davranışı gösteren öğrencilerle ilgilenmenin yanı sıra şiddet davranışı göstermeyen öğrencilere de önleyici programlar geliştirmek şiddet davranışının diğer öğrenciler arasından modellenmesini engelleyeceği için faydalı olabilir.

PDD iş birliğiyle çalışıldığında daha etkili olmaktadır. Bu nedenle şiddeti önlemede sadece okul rehber öğretmenleri değil okul müdürü, öğretmenler, kantin görevlileri, servis şoförü gibi okulun diğer çalışanları ve velilerde şiddeti önlemede okul geneli PDD sistemine dahil edilerek etkili sonuç almaya katkı sağlayabilir. Ayrıca PDD programı uygulanırken çalışanların ve velilerin nitelikli destek sağlamaları için öğretmenlere, velilere ve okuldaki diğer çalışanlara yönelik PDD programlara geliştirilebilir. 


\section{KAYNAKÇA}

Anderson, C. M. ve Kincaid, D. (2005). Applying behavior analysis to school violence and discipline problems: Schoolwide positive behavior support. The Behavior Analyst, 28, 49-63.

Bohanon, H. ve $\mathrm{Wu}$, M. J. (2014). Developing buy-in for positive behavior support in secondary settings. Preventing School Failure, 58, 4, 223-229.

Carney, K. (2005). Positive Behavior Support in High Schools: Monograph from the 2004 Illinois High School forum of positive behavioral interventions and supports. Hank Bohanon-Edmonsoni K. Brigid Flannery, Lucille Eber and George Sugai (Eds.). School-wide reinforcement systems in high schools (s.62- 72). Naperville, Illinois.

Çalık, T., Kurt, T. ve Çalık, C. (2011). Güvenli okulun oluşturulmasında okul iklimi: Kavramsal bir çözümleme. Pegem Ĕ̆itim ve Öğretim Dergisi, 1,4, 73-84.

Garcia, L. E. (2014). Positive behavioral interventions and supports: A multi-tiered framework that works for every student. An Nea Policy Brief, National Education Association, 1-6.

Gottfredson, D. C., Gottfredson, G. D. ve Hybl, L. G. (1993). Managing adolescent behavior a multiyear, multischool study. American Educational Research Journal, 30, 179-215.

Gültekin, F. (2008). Saldırganlık ve öfkeyi azaltma programının ilköğretim ikinci kademe öğrencilerinin saldırganlık ve öfke düzeyleri üzerindeki etkisi [Yayımlanmamış doktora tezi]. Hacettepe Üniversitesi.

Gürsoy, M. (2009). Öğrencilerde şiddet eğilimi ve şiddete yönelik öğretmen algıları. KKTC Milli Eğitim Dergisi, 3,13-30.

Horner, R. H., Sugai, G. ve Anderson, C. M. (2010). Examining the evidence base for school- wide positive behavior support. Focus on Exceptional Children, 42, 8,1-14.

Hoşgörür, V. ve Orhan, A. (2017). Okulda zorbalık ve şiddetin nedenleri ve önlenmesinin yönetimi (Muğla Merkez İlçe Örneği)*. Bayburt Eğitim Fakültesi Dergisi, 12 (24), 859-880.

Johnston, J. M., Foxx, R. M., Jacobson, J. W., Green, G. ve Mulick, J. A. (2006). Positive behavior support and applied behavior analysis. The Behavior Analyst, 29 (1) ,51-74.

Kızmaz, Z. (2006). Okullardaki şiddet davranışının kaynakları üzerine kuramsal bir yaklaşım. C.Ü. Sosyal Bilimler Dergisi, 30 (1), 47-70.

Knoff, H. M. (2000). Organizational development and strategic planning for the millennium; a blueprint toward effective school discipline, safety, and crisis prevention. Psychology in the Schools, 31 (1), 17-32.

Koç, B. (2011). Okullarda şiddet. (2. Baskı). Yazı Yayınevi.

Lacina, J. ve Stetson, R. (2013). Using children's literature to support positive behavior. Young Children, 34-41. 
Nelson, J. R. (1996). Designing schools to meet the needs of students who exhibit disruptive behavior. Journal of Emotional and Behavioral Disorders, 4 (3), 147- 161.

PBIS. (?). Positive behavioral sçevrim-içi: https://www.aasa.org/uploadedFiles/Childrens_Programs/PBIS\%20factsheet.pdf], Erişim tarihi: 13 Temmuz 2017.

Pişkin, M., Öğ̈̈lmüş, S. ve Boysan, M. (2011). Güvenli Ortamı Oluşturma Öğretmen ve Yönetici Kitabı. TÜBİTAK.

Ruef, M. B., Higgins, C., Glaeser, B. J. C. ve Patnode, M. (1998). Positive behavioral support: Strategies for teachers. Intervention in School and Clinic, 34, 1.

Safran, S. P. ve Oswald, K. (2003). Positive behavior supports: Can schools reshape disciplinary practices? Exceptional Children, 69, 361-373.

Sağkal, A. S. (2011). Barış Eğitimi Programının İlköğretim 6. Sınıf Öğrencilerinin Saldırganlık Eğilimleri, Empati Düzeyleri ve Barışa İlişsin Görüşleri Üzerindeki Etkisinin İncelenmesi [Yayımlanmamış yüksek lisans tezi]. Dokuz Eylül Üniversitesi.

Simonsen, B., Sugai, G. ve Negron, M. (2008). School wide positive behavior supports primary systems and practices. Positive Behavior Interventions and Supports, 40(6), 32-40.

Sprague, J., Walker, H., Golly, A., White, K., Myers, D. R. ve Shannon, T. (2001). Translating research into effective practice: The effects of a universal staff and student intervention on indicators of discipline and school safety. Education and Treatment of Children, 24, 495-511.

Sugai, G. ve Horner, R. R. (2006). A promising approach for expanding and sustaining school- wide positive behavior support. School Psychology Review, 35 (2) 245- 259.

Şahin, İ. ve Kesici, Ș. (2009). Web-assisted positive behavior support. İlköğretim Online, 8 (1), 224-230.

Uluçay, T. (2012). Müzik eğitiminin ortaöğretim öğrencilerinin şiddet eğilimlerine etkisi [Yayımlanmamış doktora tezi]. İnönü Üniversitesi.

Trend, D. (2008). Medyada şiddet efsanesi. (Çev. G. Bostancı). YKY.

Tumbull, A., Edmonson, H., Griggs, P., Wickham, D., Sailor, W., Freeman, R., et al. (2002). A blueprint for schoolwide positive behavior support: Implementation of three components. Exceptional Children, 68, 377402 .

Wilson, D. B., Gottfredson, D. C. ve Najaka, S. S. (2001). School-based prevention of problem behaviors: A metaanalysis. Journal of Quantitative Criminology, 17 (3), 247-272.

Yayla, A. (2005). Kant’ın ahlak eğitimi anlayışı. Ankara Üniversitesi Eğitim Bilimleri Fakültesi Dergisi, 38 (1), 7386 


\section{EXTENDED ABSTRACT}

\section{Introduction.}

Schools have some responsibilities and duties regarding to societies and individuals. Schools is an important place of cultural transmission and schools raise new generation for society. But sometime schools cannot fulfil duties owing to some problems such as violence and various discipline problems. Violence and these various discipline problems generally harm academia and social relationships. Punishment methods increased by the school cannot take away discipline problems including violence. As a solution to these problems, positive behavioral support should be used because studies show that this system has achieved success. The main reason for this study is to seek solutions to the problem of violence in schools by using Positive Behavior Support Program.

\section{Method.}

In the study, which is an experimental research, a pre-test-post-test control group design was used. The 2x3 split-plot (mixed) pattern used in the study was used. The independent variable of the study is the Positive Behavior Support Program; Dependent variables are students' level of tendency to violence and time factor. 8 weeks of PBS program was applied to the experimental group. Free Activity Program was applied to the control group.

The research group was chosen from Van / Edremit Orhan Okay Vocational and Technical Anatolian High School. These students were the students who continue their 9th and 10th grade in the 2016-2017 academic year. Personal information form and Violence Tendency Scale were applied to 221 students. 24 students with the highest score from the Violence Tendency Scale participated in the study. Students were randomly assigned to the experimental group.

\section{Results.}

Before and after the experimental, violence tendency score levels of the subjects taking part in "Positive Behavioral Support Programme" showed a significant difference. As regards to the results of multiple comparison tests, the post test mean of experimental group $(\overline{\mathrm{x}}=33,5833)$ is significantly lower than the pretest average of experimental group $(\bar{x}=42,5833)$. Morever, the average of follow-up test performed after two mounts $(\bar{x}=38,3833)$ is smaller than the pretest average. However, although according to the results of the analysis, there is a significant difference between the pretest and the post test, there is not a significant difference between the post test and the follow-up test. Thus, it can be said that violence tendency levels of the subjects taking part in the experimental decrease; yet this change is not permanent. In addition, there was no a significant difference among the pre-test $(\overline{\mathrm{x}}=41.9167)$, post test $(\overline{\mathrm{x}}=38.2500)$ and follow-up test $(\overline{\mathrm{x}}=38.0833)$ of the control group.

\section{Discussion \& Conclusion.}


Violence in school cause many problems. Schools often try to solve disciplinary problems, especially violence, through punishment methods. Despite the many methods used, problems of violence in schools persist. Positive Behavior Support is widely used for violence and disciplinary problems in schools in Europe and America. Violence and similar problems decrease in schools where PBS is used effectively and continuously.

This research examining the effect of PBS program on violence tendency is an experimental study. When the effect of Positive Behavior Support Program on violence tendency behavior was examined, a significant difference was found between the pre-test and post-test of the experimental group. This finding is similar to previous studies. Simonsen, Sugai, and Negron (2008) state in their study that discipline problems experienced in schools and aggressive behaviors among students are resolved within the PBS system.

In this study, although there was a significant difference between pre-test and post-test, no significant difference was found between post-test and follow-up test. Although the PBS program was successful in reducing the tendency to violence, the continuation of this well-being was not observed. This finding was consistent with the PBS theory. According to PBS, PBS should be continuous in order to reduce problematic behaviors at school and to maintain good health (Knoff, 2000). 